\title{
Penguatan Dakwah Virtual sebagai Upaya Memakmurkan Masjid Berbasis Kegiatan Remaja Masjid
}

\author{
Farida Hariyati1 $^{1}$ dan Dini Wahdiyati $^{1}$ \\ ${ }^{1}$ Program Studi Ilmu Komunikasi, Universitas Muhammadiyah Prof. DR. Hamka, Jl. Limau II Kebayoran \\ Baru, Jakarta Selatan, Indonesia \\ *Email korespondensi: farida@uhamka.ac.id
}

\begin{abstract}
Abstrak
Dakwah tidak dapat ditinggalkan dari keberadaan masjid sebagai pusat ibadah dan pengembangan keilmuan. Transformasi pemanfaatan media digital telah merambah ke berbagai kebutuhan komunikasi, termasuk didalamnya strategi dalam berdakwah secara virtual dengan memanfaatkan media social. Dakwah tidak lagi dilakukan oleh kelompok-kelompok yang dianggap mumpuni dalam pemahaman agama namun setiap individu dapat melakukan dakwah virtual ini. Dalam kerangka memakmurkan masjid, Remaja Masjid Mubasysyirin (REISMI) Setiabudi Jakarta Selatan mulai memanfaatkan media social untuk menyebarkan nilai-nilai positif keagamaan namun belum diiringi dengan kesadaran pentingnya konsep dan strategi yang kuat dalam pesan-pesan persuasif dakwah virtual sehingga mereka sangat membutuhkan penguatanpenguatan. Metode dalam pengabdian masyarakat ini dilakukan dengan memperkuat konsep dakwah virtual, branding remaja masjid, dan pelatihan audio visual untuk membuat konten kreatif media social yang menarik perhatian kaum muda milenial. Hasil dari kegiatan pengabdian masyarakat menunjukkan adanya kesadaran social REISMI untuk merancang strategi dakwah virtual melalui konten kreatif media social dan meningkatnya kreatifitas dalam menentukan ide dalam rangka menebarkan nilai-nilai agama bagi remaja.
\end{abstract}

Kata kunci: Dakwah Virtual, Memakmurkan Masjid, Remaja Masjid, Media Sosial

\begin{abstract}
Da'wah cannot be left out of the existence of the mosque as a center of worship and knowledge development. The transformation of the use of digital media has penetrated into various communication needs, including strategies in preaching virtually by utilizing social media. Da'wah is no longer carried out by groups that are considered qualified in the understanding of religion, but each individu can do da'wah activities. Within the framework of empowerment of masjid, Youth of the Mubasysyirin Masjid (REISMI) Setiabudi South Jakarta began to utilize social media to spread positive religious values but have not been accompanied by an awareness of the importance of strong concepts and strategies in persuasive messages of virtual proselytizing so they urgently need reinforcement concepts. The method carried out in this community services were by strengthening the concept of virtual da'wah, branding of youth of masjid, and audio-visual training to create creative social media content that attracts the attention of millennial youth. The results of community service activities indicate REISMI's social awareness to design virtual preaching strategies through creative social media content and increased creativity in determining ideas in order to spread religious values for adolescents.
\end{abstract}

Keywords: Virtual Da'wah, Empowerement of Masjid, Masjid Youth, Social Media

Format Sitasi: Haryati, F., \& Wahdiyati, D. (2019). Penguatan Dakwah Virtual Sebagai Upaya
Memakmurkan Masjid Berbasis Kegiatan Remaja. Jurnal Solma, 8(2), 239-247. Doi:
http://dx.doi.org/10.29405/solma.v8i2.3392

Diterima: 30 April 2019 | Revisi: 04 Oktober 2019 | Dipublikasikan: 21 Oktober 2019

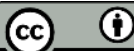

(C) 2019. Oleh authors. Lisensi Jurnal Solma, LPPM-Uhamka, Jakarta. Artikel ini bersifat open access yang didistribusikan di bawah syarat dan ketentuan Creative Commons Attribution (CC-BY) license. (http://creativecommons.org/licenses/by/4.0/). 


\section{PENDAHULUAN}

Dakwah adalah kebutuhan manusia dalam kehidupan spiritualitasnya, dan dalam aktivitasnya, dakwah dapat dilakukan melaluim berbagai cara, baik melalui ceramah, khutbah, maupun tulisan (Risdiana \& Ramadhan, 2019). Namun, di era teknologi saat ini, dakwah tidak cukup melalui cara-cara konvensional. Era globalisasi telah berimplikasi pada munculnya masyarakat informasi. Masyarakat informasi menemukan kemudahan berlimpah sejak memasuki era internet. Masyarakat pun semakin mudah terhubung untuk saling berinteraksi. Mereka berkomunikasi, berperilaku, bekerja, dan berpikir sebagai masyarakat digital (digital native) (Supratman, 2018). Masyarakat digital menjadi tren era teknologi yang kemudian menghasilkan berbagai platform media baru. Teknologi merupakan salah satu hal penting dalam mempengaruhi karakter generasi penerus bangsa (Restendy, 2018).

Dakwah tentu saja tidak dapat ditinggalkan dari keberadaan masjid. Masjid merupakan tempat yang suci yang tidak asing lagi kedudukannya bagi umat Islam. Masjid selain sebagai pusat ibadah umat Islam, ia pun sebagai lambang kebesaran syiar dakwah Islam (Nasikin, 2017) . Masjid merupakan tempat yang paling strategis dalam membina dan menggerakkan potensi umat Islam untuk mewujudkan sumber daya insani yang tangguh dan berkualitas (Siswanto, 2019). Sumber daya insani yang diharapkan mampu menjadi penggerak dakwah sekaligus sebagai bagian dari upaya memakmurkan masjid adalah remaja masjid. Melalui peran remaja masjid, masjid mampu menjadi wadah pembentukan akhlakul karimah serta pendidikan akhlakul karimah bagi masyarakat sekitar khususnya remaja-remaja yang dalam dunia nyata pergaulannya kini sangat rawan (Nevihwa, Maya, \& Yasyakur, 2018).

Perubahan fokus dari pemanfaatan media konvensional ke media digital kini telah merambah ke berbagai kebutuhan komunikasi (Baran \& Davis, 2010) . Kebutuhan dan minat masyakarat terutama kelompok remaja dalam memenuhi kebutuhan pemahaman terhadap ajaran agama Islam menjadi pendorong remaja untuk memanfaatkan media social sebagai platform yang mudah diakses dan mampu memberi informasi dengan cepat. Digital literacy yang dimiliki kelompok remaja menjadi cara yang mudah untuk beradaptasi dengan media-media baru berbasis internet (Tjahyadi, 2007).

Dakwah virtual telah menjadi alternatif dalam dakwah di era digital. Pemanfaatan media sosial untuk berdakwah secara virtual ini kemudian dapat menjadi saluran (channel) dakwah yang efektif jika dirancang dengan kreatif melalui pesan-pesan yang menarik 
untuk dijadikan preferensi bagi remaja. Remaja masjid dapat melakukan aktivitas ibadah dan sosial melalui media sosial. Remaja masjid di wilayah perkotaan tentu memiliki tantangan tersendiri di tengah arus informasi dan hiburan yang mampu memapar kehidupan social remaja perkotaan.

Remaja Masjid Mubasysyirin yang berada di tengah Ibukota Jakarta memiliki semangat dakwah guna berupaya memakmurkan masjid. Masjid Mubasysyirin memiliki fasilitas sambungan internet yang cukup memadai. Fasilitas ini dapat dimanfaatkan untuk menunjang perumusan, produksi, pengembangan dan proses distribusi pesan-pesan dakwah berbasis data digital (Wasesa, 2011). Remaja Masjid Mubasysyirin telah memulai aktivitas dakwah virtual melalui postingan video di media sosial Instagram. Baru-baru ini salah satu konten yang pernah dibuat adalah berupa counter tren "Seberapa Geregetnya Kamu" yang kemudian viral di media sosial dengan mengkontekskan pesannya pada pesan ala remaja islami (Nuraini \& Muhtarima, 2016) . Aktivitas awal ini telah menunjukkan semangat berdakwah secara virtual bagi remaja masjid, namun Remaja Masjid Mubasysyirin (REISMI) belum memiliki konsep yang kuat dalam rangka merancang pesan-pesan persuasif dakwah virtual sehingga mereka sangat membutuhkan penguatan-penguatan. Hal ini disampaikan oleh beberapa pengurus REISMI bahwa mereka membuat konten hanya sebatas ketika muncul ide saja, belum terprogram dan memiliki timeline yang sistematis, Meskipun mereka menyadari bahwa apa yang mereka posting adalah pesan yang sarat dengan nilai agama dan pengingat bagi generasi muda muslim (Weiss, 2018).

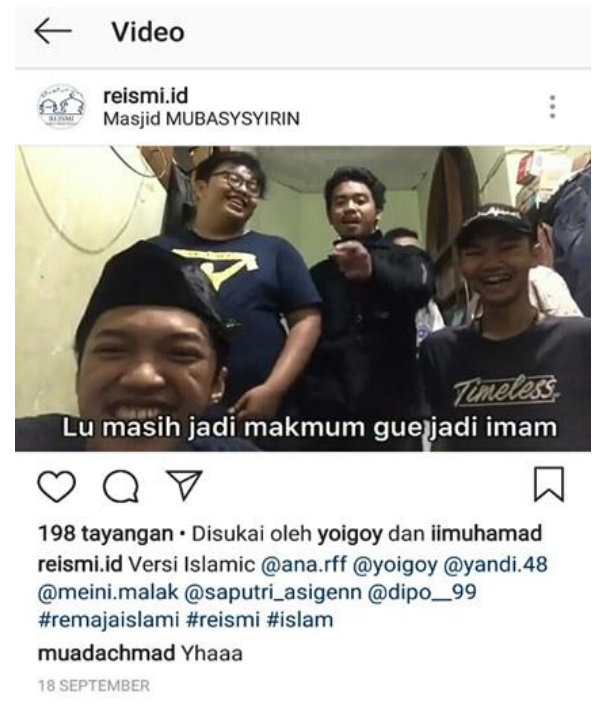

Gambar 1. Tangkapan Layar Video "Seberapa Gregetnya Kamu” karya Remaja Masjid Mubasysyirin yang sudah viral di media sosial 


\section{MASALAH}

Kurangnya penguasaan konsep dan strategi dalam pemanfaatan media sosial untuk berdakwah menjadi permasalahan tersendiri bagi mitra. Media sosial yang telah banyak dimanfaatkan hanya sekadar "iseng-iseng" digunakan tetapi tidak digunakan sebagai media dakwah virtual yang pesannya sengaja dibuat dengan sistematis dan terstruktur sehingga ada tujuan yang jelas dan terukur. Sehingga dapat dirumuskan hal-hal yang menjadi permasalahan mitra adalah (1) dakwah virtual hanya dilakukan "iseng-iseng" bukan dijadikan kegiatan dakwah yang pesannya sistematis dan terstruktur sehingga dapat diukur efektivitasnya; dan (2) Belum disadari bahwa dakwah virtual dapat meningkatkan 'branding' remaja masjid sebagai salah satu kelompok strategis untuk menyebarkan nilainilai agama di era milenial dan kekinian terutama bagi remaja; (3) kurangnya penguasaan konsep dan strategi dalam implementasi dakwah virtual yang dilakukan melalui konten kreatif.

\section{METODE PELAKSANAAN}

Kegiatan Program Kemitraan Masyarakat dilakukan dengan menerapkan berbagai metode, yaitu edukasi dengan memberikan sosialisasi dan penguatan teoritis oleh kedua narasumber dari Tim, dan pelatihan audio visual, membuat konten kreatif melalui karya film pendek (short movie) untuk diposting melalui media social Instagram yang disampaikan oleh Narasumber dari Production House "Rumah Kreatif Condet" (RKC). Adapun langkah-langkah yang ditempuh oleh tim adalah : (1) mengumpulkan informasi awal dengan cara melakukan observasi awal dan wawancara dengan pengurus REISMI dalam rangka pemetaan masalah; (2) Mengidentifikasi masalah, dimana tim melakukan identifikasi masalah dan menyepakati solusi untuk memberikan penguatan berupa pemahaman konseptual dan pelatihan bagi REISMI; (3) memberikan solusi yakni menyampaikan penguatan tentang pentingnya media social untuk sarana dakwah virtual, memetakan media-media yang potensial sebagai saluran dakwah, dan memberikan pelatihan dari praktisi media social untuk meningkatkan literasi digitasl khususnya terkait konten kreatif melalui audio visual untuk diposting melalui media sosial; (4) melakukan koordinasi tim dengan pengurus REISMI dan Dewan Takmir Masjid Mubasysyirin terkait persiapan dan jadwal kegiatan; (5) pelaksanaan kegiatan, kegiatan dilaksanakan selama 2 (dua) hari, yaitu tanggal 23 dan 24 Februari 2019 bertempat di Aula Masjid Mubasysyirin, Setiabudi Jakarta Selatan. 


\section{HASIL DAN PEMBAHASAN}

Kegiatan Pengabdian Masyarakat dilaksanakan dengan mitra Remaja Masjid Mubasysyirin (REISMI), Setiabudi, Jakarta Selatan dan REISMI menjadi panitia penyelenggara dalam kegiatan tersebut dengan memberikan kontribusi dalam : (1) penentuan tempat dan waktu kegiatan; kegiatan dilaksanakan sebagai bagian dari program kerja REISMI dalam bidang publikasi; (2) koordinasi dengan Dewan Takmir Masjid terkait perizinan tempat; (3) mobilisasi peserta kegiatan. Kegiatan ini diikuti oleh sejumlah 20 orang pengurus REISMI dengan tingkat pendidikan yang bervairasi, mulai dari siswa SLTP hingga mahasiswa; dan (4) pengelola acara; dimana petugas acara seperti registrasi, MC, qori, dokumentasi, dan konsumsi semua dilakukan oleh pihak REISMI.

Acara dimulai dengan pembacaan ayat suci Al Qur'an dan pembukaan oleh Ketua Dewan Takmir Masjid Mubasysyirin serta Ketua REISMI sebagai tuan rumah. Acara selanjutnya adalah penguatan-penguatan yang diberikan oleh Tim Pengabdi. Narasumber pertama, Dini Wahdiyati, S.Sos, MIKom menyampaikan materi berkaitan dengan konsep dakwah virtual. Dakwah virtual dapat dimaknai sebagai ajakan kepada manusia menuju jalan yang diridlai Allah dengan menggunakan media (washilah) internet. Saat ini dakwah virtual menjadi sebuah pendekatan baru dalam strategi dakwah yang sangat mungkin dilakukan dengan media-media social yang dapat diakses oleh remaja, termasuk remaja masjid Mubasysyirin. Dalam perspektif persyarikatan, gagasan dakwah virtual menjadi salah satu rumusan hasil Muktamar Muhammadiyah Tahun 2015 di Makassar. Dakwah virtual merupakan dakwah bi ahsanil qawl: dakwah dengan lisan, tulisan, gambar, dan lambang dalam bentuk audio, video, dan audio visual yang berbasis internet, serta memiliki konteks public, massa, dan sosial. Dalam dakwah virtual, siapapun dapat menjadi pelaku dakwah, tidak hanya yang sering disebut 'ustadz'/'ustadzah' atau 'kyai' karena pada dasarnya dalam Islam, menyampaikan kebaikan itu adalah kewajiban setiap muslim. Maudu' (tema/topik) dakwah virtual tentu dapat berkaitan dengan aqidah, akhlak, ahkam, ukhwah, pendidikan, sosial, kebudayaan, kemasyarakatan, amar makruf dan nahi munkar, dan isu-isu aktual lain, dengan catatan bahwa kemasan (packaging) tema-tema tersebut harus disesuaikan dengan pola pikir generasi milinial dan disesuaikan dengan media yang digunakan.

Sementara itu, narasumber kedua, Farida Hariyati, SIP. MIKom.menyampaikan materi tentang branding remaja masjid melalui dakwah virtual. Remaja masjid terkadang dipahami sebagai remaja yang kurang pergaulan, antiteknologi, dan kuno. Padahal 
sesungguhnya di jaman milenial ini, remaja menjadi kelompok yang berpotensi untuk menyampaikan banyak pesan kebaikan melalui media media social seperti facebook, twitter, dan Instagram. Branding merupakan kegiatan komunikasi yang dilakukan baik oleh perusahaan maupun perorangan untuk membangun dan membesarkan merk atau brand. Brand dalam konteks ini tentu saja bukan saja dimaknai barang atau produk, melainkan juga individu, sehingga disebut Personal Branding. Personal Branding merupakan usaha atau upaya yang dilakukan oleh seseorang untuk menjadikan diri mereka sebagai brand yang dikenal dan diingat sehingga memiliki penilaian atau pandangan tersendiri dari masyarakat umum. Personal brand dapat merefleksikan "pembeda khas" ataupun menunjukkan keunikan seseorang. Terkait dengan remaja masjid, maka ketrampilan dalam berdakwah secara virtual di media soial melalui konten-konten kreatif dapat menjadi komoditi personal branding untuk memberikan distingsi dan pada akhirnya meningkatkan citra remaja masjid di jaman milenial (Nasrullah, 2015) .
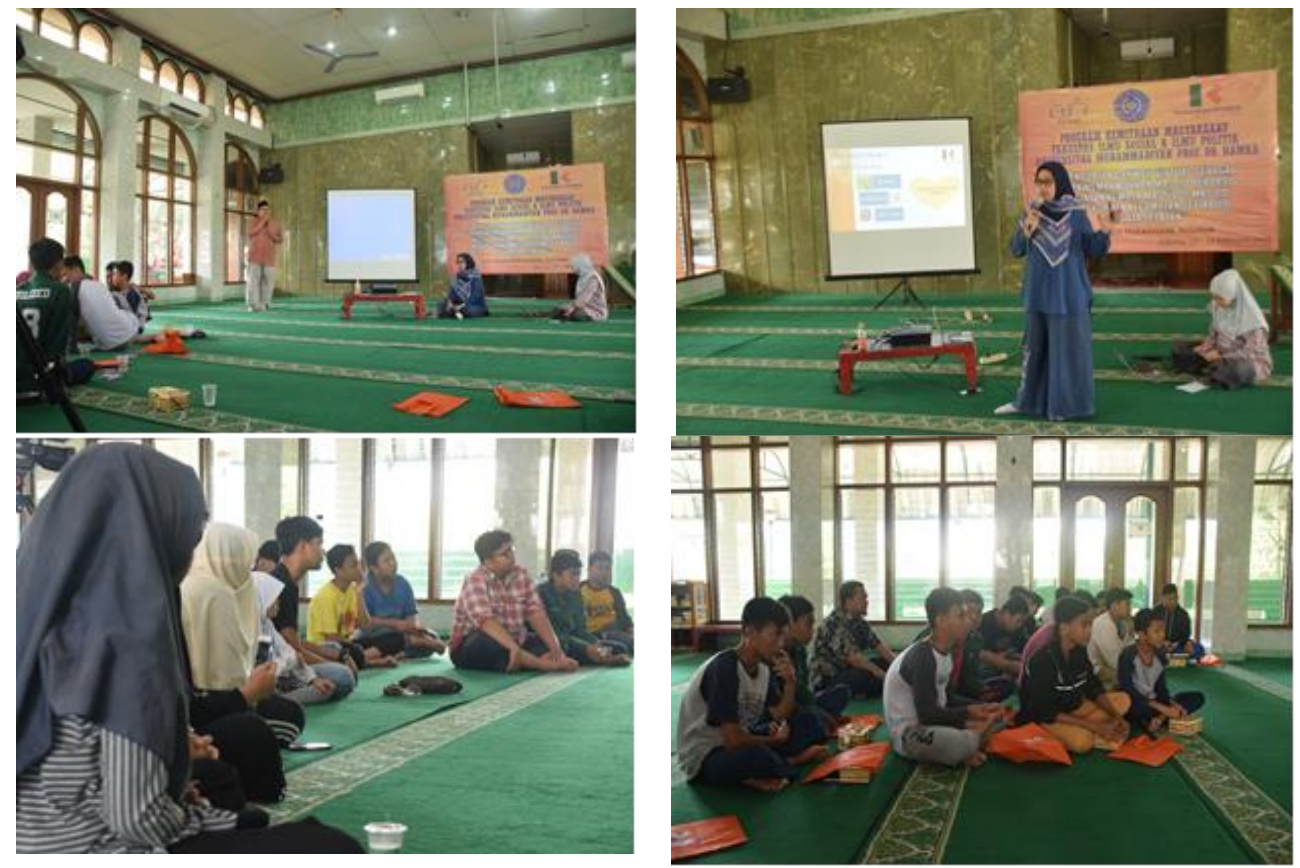

Gambar 2. Pemaparan Materi oleh narasumber

Pelatihan membuat konten kreatif oleh RKC dilaksanakan pada hari Ahad, 24 Februari 2019, dengan narasumber: Ihsan Kamil dan Chimbs Kribo. Narasumber memberikan materi tentang pembuatan film pendek dengan memperhatikan proses-proses, dari proses pra produksi, proses awal, proses produksi, dan proses pascaproduksi, serta bagaimana mekanisme mempromosikan hasil film yang telah dibuat oleh para peserta sehingga mendapatkan respon yang baik dari penonton, atau subscriber, atau viewer. 
Setelah paparan materi, peserta diberikan tugas untuk membuat sebuah video pendek dengan memberdayakan sumber daya peserta, baik sebagai content creator, kru maupun talent (Surjono, 2013) . Kegiatan praktik membuat video pendek ini menjadi sebuah tantangan yang menyenangkan bagi para peserta pelatihan karena mereka mengalami secara langsung bagaimana membuat sebuah video untuk dakwah virtual yang kreatif dengan dipandu para professional (Astuti, 2002) .

Rangkaian kegiatan program kemitraan masyarakat telah dilaksanakan dengan baik dan mendapatkan respon positif serta antusiasme dari para peserta yang berusia remaja dan aktif di kegiatan Remaja Masjid Mubasysyirin, Setiabudi, Jakarta Selatan. Dengan dilaksanakannya program kemitraan ini, maka dapat memberikan stimulus awal bagi penguatan dakwah virtual di era milenial yang sangat mungkin dilakukan oleh remaja tersebut. Hasil dari pelatihan ini para peserta membuat karya berupa video pendek dengan judul "SEDEKAH" dengan dipandu secara langsung oleh rumah produksi Rumah Kreatif Condet sebagai narasumber praktisi. Video ini diproyeksikan akan diunggah pada akun Youtube sebagai karya otentik Remaja Masjid Mubasysyirin sebagai langkah awal untuk memulai gerakan dakwah virtual bagi generasi millennial (George et al., 2013).

Luaran dari kegiatan Pengabdian kepada Masyarakat ini adalah adanya kesadaran dakwah virtual yang dilakukan oleh REISMI perlu didirancang dengan lebih strategis, sistematis, dan terstruktur; REISMI memperoleh kesadaran bahwa dakwah virtual melalui media social dapat meningkatkan 'branding' remaja masjid sebagai kelompok strategis dalam menyebarkan nilai-nilai agama; dan terbangunnya penguasaan konsep dan strategi dakwah virtual melalui pengemasan pesan dalam konten-konten kreatif.
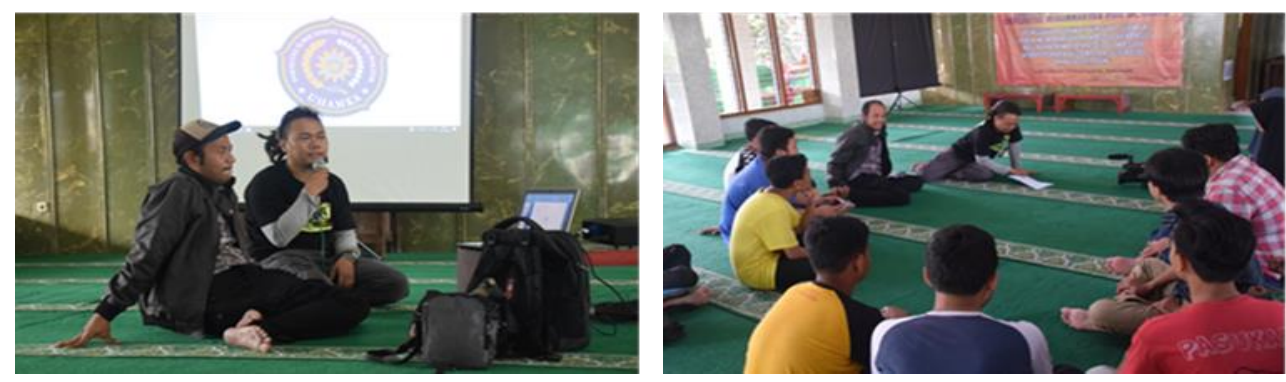

Gambar 3. RKC sedang memberikan pelatihan konten kreatif

\section{KESIMPULAN}

Dari hasil kegiatan pengabdian masyarakat dapat digarisbawahi beberapa kesimpulan bahwa rangkaian penguatan konsep dakwah virtual, branding, dan pelatihan konten kreatif memberikan peningkatan pemahaman, kesadaran, dan keterampilan pada pengurus 
REISMI, namun ada beberapa kelemahan bahwa maka kegiatan tersebut seyogyanya dilakukan secara berkelanjutan sehingga REISMI tetap mendapatkan pendampingan secara intensif dalam melakukan dakwah virtual.

\section{UCAPAN TERIMA KASIH}

Tim abdimas mengucapkan terima kasih yang setulus-tulusnya kepada Lembaga Pengabdian dan Pemberdayaan Masyarakat (LPPM) UHAMKA yang telah memberikan dukungan dan bantuan baik merupa materiil maupun non materiil sehingga kegiatan Program Kemitraan Masyarakat dapat terlaksana dengan lancar dan memberikan manfaat bagi peserta. Terima kasih pula kepada seluruh jajaran pengurus dan anggota Remaja Islam Masjid Mubasysyirin dan Pimpinan Cabang Pemuda Muhammadiyah Setiabudi sebagai mitra yang mempercayakan kepada tim untuk memberikan edukasi terkait dakwah virtual bagi remaja.

\section{DAFTAR PUSTAKA}

Astuti, S. (2002). Tinjauan Aspek Mutu dalam Kegiatan Industri Pangan. Institut Pertanian Bogor.

Baran, S. J., \& Davis, D. K. (2010). Teori Komunikasi Massa: Dasar, Pergolakan, dan Masa Depan. Jakarta: Penerbit Salemba Humanika.

George, P., Dumenco, L., Dollase, R., Taylor, J., Wald, H., \& Reis, S. (2013). Introducing technology into medical education: Two pilot studies. Patient Education and Counseling, 293(3), 522-524. https://doi.org/https://doi. org/10.1016/j.pec.2013.04.018.

Nasikin, M. (2017). Memakmurkan Masjid Melalui Gerakan Shalat Berjama'ah di Desa Parampuan Kecamatan Labuapi Kabupaten Lombok Barat. El-Tsaqafah: Jurnal Jurusan PBA, 16(1), 93-102. Nevihwa, N., Maya, R., \& Yasyakur, M. (2018). Peran Perhimpunan Remaja Masjid At-Taqwa (Permat. El-Tsaqafah: Jurnal Jurusan PBA, 16(1), 93-102.

Nasrullah, R. (2015). Media Sosial Perspektif Komunikasi, Budaya, dan Sosioteknologi. Bandung: Simbiosa Rekatama Media.

Nevihwa, N., Maya, R., \& Yasyakur, M. (2018). Peran Perhimpunan Remaja Masjid AtTaqwa (Permata) Dalam Meningkatkan Akhlakul Karimah Masyarakat Kampung Ciampea Ilir Desa Tegalwaru Kecamatan Ciampea Kabupaten Bogor. Prosa PAI: Prosiding Al Hidayah Pendidikan Agama Islam, 1(1), 19-27.

Nuraini, N., \& Muhtarima, M. F. (2016). Implementasi Kurikulum 2013 Pada Mata Pelajaran Pendidikan Agama Islam di SD Muhammadiyah Terpadu Ponorogo. Jurnal Pendidikan Islam, 1, 52-80. 
Restendy, M. S. (2018). Dakwah Virtual Yayasan Spirit Dakwah Indonesia (SPIDI) Tulungagung. In Proceedings of Annual Conference for Muslim Scholars (pp. 298$305)$.

Risdiana, A., \& Ramadhan, R. B. (2019). Dakwah Virtual sebagai Banalitas Keberagamaan di Era Disrupsi. FIKRAH, 7(1), 133-154.

Siswanto, B. (2019). Peranan Masjid Dalam Membentuk Karakter Akhlak Muslim Mahasiswa Stsn. Tadrib, 5(1), 21-33.

Supratman, L. P. (2018). Penggunaan Media Sosial oleh Digital Native.

Surjono, H. D. (2013). Peranan Teknologi Informasi dan Komunikasi (ICT) dalam Peningkatan Proses Pembelajaran yang Inovatif. Seminar Nasional Pendidikan \& Saintec UMS.

Tjahyadi, S. (2007). Ilmu Teknologi dan Kebudayaan. yogyakarta: Liberty Yogyakarta.

Wasesa, S. A. (2011). Political Branding \& Public Relations. Jakarta: PT Gramedia.

Weiss, M. L. (2018). Media Power in Indonesia: Oligarchs, Citizens and The Digital Revolution by Ross Tapsell (Review). USA: Cornell University Press. 